\begin{tabular}{|c|c|c|}
\hline BIODIK & $\begin{array}{c}\text { BIODIK: Jurnal IImiah Pendidikan Biologi } \\
\text { ISSN 2580-0922 (online), ISSN 2460-2612 (print) } \\
\text { Volume 07, Nomor 04, Tahun 2021, Hal. 10-17 } \\
\text { Available online at: } \\
\text { https://online-journal.unja.ac.id/biodik }\end{array}$ & BIODIK ( ) \\
\hline
\end{tabular}

Research Article

OPEN ACCESS

\title{
Perbedaan Hasil Belajar Kognitif Siswa Pada Pembelajaran Daring Melalui Google Classroom dan Whatsapp Mesenger Di SMP Negeri 4 Bengkulu Tengah
}

\section{(Differences in Student Cognitive Learning Outcomes in Online Learning Through Google Classroom and Whatsapp Messenger at SMP Negeri 4 Bengkulu Tengah)}

\author{
Alianto ${ }^{1 *}$, R Hasan², Irwandi2 \\ 1SMP Negeri 4 Bengkulu Tengah \\ 2Magister Pendidkan Biologi Universitas Muhammadiyah Bengkulu \\ Jl. Bali, Kp. Bali, Kec. Tlk. Segara, Kota Bengkulu, Bengkulu 38119 \\ *Corresponding author: aliantorizki@gmail.com
}

\begin{tabular}{ll}
\hline Informasi Artikel & \multicolumn{1}{c}{ ABSTRACT } \\
\hline Submit: $29-08-2021$ & Cognitive learning outcomes of students in learning biology are still low. This \\
Diterima: $15-11-2021$ & study aims to determine the differences in students' cognitive learning outcomes \\
Dipublikasikan: $13-12-2021$ & in online learning through google classroom and whatsapp messenger at SMP \\
& Negeri 4 Bengkulu Tengah. The research was carried out in January-March \\
& 2021, using pre-experimental research methods, pre-experimental one group \\
& pre-test-post-test design. The population is class VIII SMPN 4 Bengkulu Tengah, \\
& totaling 86 students, with a sample of 43 students. Collecting data with test \\
& questions of students' cognitive learning outcomes. The results showed that \\
& there was no difference between students' cognitive learning outcomes in online \\
& learning through google classroom and whatsapp messenger at SMPN 4 \\
& Bengkulu Tengah. \\
& Key words: learning outcomes, google classroom and whatsapp messenger \\
\hline & ABSTRAK \\
\hline Penerbit & Hasil belajar kognitif siswa dalam pembelajaran biologi masih rendah. Penelitian \\
Program Studi Pendidikan Biologi & ini bertujuan untuk mengetahui perbedaan hasil belajar kognitif siswa pada \\
Jambi- Indonesia & pemebelajaran daring melalui google classroom dan whatsapp mesenger Di \\
& SMP Negeri 4 Bengkulu Tengah. Penelitian dilaksanakan pada bulan Januari- \\
& Maret 2021, menggunakan metode penelitian pra eksperimen, desain pre- \\
& eksperiment one group pre-test-post-test. Populasi adalah siswa kelas VIII \\
& SMPN 4 Bengkulu Tengah yang berjumlah 86 siswa, dengan sampel 43 siswa. \\
& Pengumpulan data dengan soal tes hasil belajar kognitif siswa. Hasil penelitian \\
& menunjukkan bahwa tidak terdapat perbedaan antara hasil belajar kognitif siswa \\
& pada pembelajaran daring melaui google classroom dan whatsapp mesenger Di \\
& SMPN 4 Bengkulu Tengah. \\
&
\end{tabular}

This BIODIK : Jurnal IImiah Pendidikan Biologi is licensed under a CC BY-NC-SA (Creative Commons Attribution-ShareAlike 4.0 International License) 


\section{PENDAHULUAN}

Covid 19 yang telah melanda di Indonesia sejak Februari 2019 memberikan perubahan dalam berbagai aspek kehidupan, tak terkecuali aspek pendidikan. Dunia pendidikan mengharuskan semua elemen beradaptasi dalam proses pembelajaran Herliandry, dkk (2020) dan telah mengganggu proses belajar mengajar secara konvensional atau tatap muka (Sadikin dan Hamidah, 2020).

Menurut mendikbud (2020) tentang pelaksanaan kebijakan pendidikan dalam masa darurat penyebaran covid-19. Dimana proses pembelajaran dilakukan dari rumah dengan ketentuan sebagi berikut: (1) Belajar dari rumah melalui pembelajaran daring/jarak jauh dilaksanakan untuk memberikan pengalaman belajar yang bermakna bagi siswa, tanpa terbebani dengan pencapaian kurikulum untuk kenaikan kelas maupun kelulusan. (2) Belajar dari rumah difokuskan pada pendidikan kecakapan hidup antara lain mengenai pandemi covid-19. (3) Aktivitas tugas dan pembelajaran dari rumah dapat bervariasi antar siswa, sesuai dengan minat dan kondisi masing-masing, termasuk mempertimbangkan kesenjangan akses/fasilitas belajar dari rumah. (4) Bukti atau produk aktivitas belajar dari rumah diberi umpan balik yang bersifat kualitatif dan berguna dari guru, tanpa diharuskan memberikan skors/nilai kuantitatif. Pelaksanaan kebijakan pendidikan tersebut membuat para guru harus menggunakan strategi untuk mengatasi masalah tersebut, dimana strategi yang di gunakan oleh para guru pada saat ini yaitu dengan pembelajaran daring menggunakan internet atau pembelajaran yang megharuskan belajar dari rumah.

Rahman dan Bahtiar (2017) menyatakan hasil belajar kognitif merupakan pengetahuan yang diperoleh peserta didik setelah mengikuti proses pembelajaran. Hasil belajar kognitif merupakan salah satu tolak ukur keberhasilan peserta didik dalam mencapai kompetensi yang telah ditentukan oleh kurikulum. Hasil belajar juga sering diartikan tingkat keberhasilan yang dicapai oleh siswa padaakhir kegiatan pada setiap mata pelajaran.

Berdasarkan observasi langsung yang dilaksanakan di SMPN 4 Bengkulu Tengah: (1) Pembelajaran dimasa pandemi dilakukann secara luring dalam bentuk fortofolio. (2) Siswa kurang aktif dalam belajar terlihat dari banyaknya siswa yang tidak mengumpulkan tugas yang diberikan oleh guru. (3) Hasil evaluasi pembelajaran menunjukkan penurunan hasil belajar siswa. Hal ini sebagaimana data laporan hasil belajar siswa dalam belajarpun mengalami penurunan, karena komunikasi antara guru dan siswa tidak tersampaikan dengan baik.

Media pembelajaran bebasis internet adalah salah satu media yang cukup relevan dalam menghadapi permasalahan dalam pembelajaran di saat ini. Menurut Rikizaputra dan Sulastri (2020) Google classroom merupakan ruang kelas terstukur dalam proses pembelajaran yang ada saat ini. Mahardani (2020) Google Classroom (Ruang Kelas Google) adalah suatu aplikasi pembelajaran secara online yang dapat digunakan oleh semua lingkup pendidikan yang membantu guru dan siswa berbagi file dalam kegiatan belajar mengajar. Aplikasi google classroom dapat di download di handphone android siswa secara gratis. Proses pembelajaran melalui google classroom sangat mudah dilakukan, pemberian tugaspun sangat menghemat waktu karena guru memberikan tugas tanpa kertas. Selain itu materi ajar juga masih dapat diakses walaupun siswa sudah tidak berada di kelas lagi. Berbagai kemudahan memang disajikan oleh kemajuan teknologi hari ini yang mendukung terwujudnya pembelajaran yang lebih efektif. 
Mu'minah dan Gaffar (2020) Kelemahan dari Google Classroom berkaitan dengan privasi data. Karena data guru maupun peserta didik terkumpul menjadi satu, ada kehati-hatian bahwa data tersebut dapat dimanfaatkan oleh Google untuk kepentingan lain. Kelemahan lainnya yang sering disebutkan adalah tidak adanya fitur laporan evaluasi akhir untuk peserta didik, peserta didik tidak dapat mengubah tugas yang telah dikumpulkan . tidak ada dukungan untuk layanan eksternal yang mungkin dibutuhkan guru.

Google Classroom kurang menarik. Hanya menampilkan beberapa pilihan gambar dan itu hanya berupa gambar cartoon. Google Drive yang kita miliki penuh maka file atau dokumen yang kita kirim ke pengajar menjadi eror dan tidak terkirim. Ini sangat menggangu sekali bagi seorang siswa dan mengakibatkan dia harus membeli drive baru atau menginstall penyimpanan awan atau cloud storage yang baru. Kemudian dihubungkan ke Google Classroom terlebih dahulu sebelum menggunakan Google Classrom tersebut supaya bisa digunakan. Google Drive mencapai batas penyimpananya, maka setiap file yang dikirim tidak akan masuk ke Google Classroom. Apabila kita ingin mengirim file ke Google Classroom kita bisa mengatur waktu pengirimanya (Rikizaputra dan Sulastri, 2020).

Menurut Kamil dan Nuryadin (2019) Whatsapp Mesengger merupakan alat komunikasi on line yang memungkinkan guru membentuk kelas virtual, forum diskusi, agenda pembelajaran, tugas terstruktur, kuis, pemeriksaan tugas. Untuk mengatasi berbagai masalah yang muncul maka pendidik harus meningkatkan kemampuan dalam penggunaan media pembelajaran yang dapat melibatkan peserta didik agar peserta didik dapat aktif dan percaya diri dalam menuangkan ide-ide yang dimilikinya selama proses belajar mengajar berlangsung.

Rahartri (2019) Menggunakan whatsapp Mesenger memiliki kelemahan antara lain: (1) tidak adanya fitur scroll ke percakapan yang belum terbaca, fitur ini sangat dibutuhkan di grup WA karena, tanpa ini akan kesulitan scrool ke atas untuk mencari pesan yang belum terbaca. (2) banyak menghabiskan disk smartphone disebabkan karena enkripsi end-to-end WA, yang membuat semua pesan dan media tersimpan pada perangkat bukan di server WA. untuk pengguna yang tidak mematikan fitur otomatis simpan media. Ini membuat aplikasi WA kalian mendownload semua media di chat dan yang dikirim di grup. (3) tidak adanya fitur filter dan report pada whatsapp terkadang banyak disalahgunakan orang, untuk mengirim pesan yang tidak pantas.

\section{METODE PENELITIAN}

Penelitian ini menggunakan metode penelitian pra eksperimen. Desain penelitian yang digunakan adalah pre-eksperiment one group pre-test-posttest.

Tabel 1. Desain one group pre-test post-test

\begin{tabular}{ccc}
\hline Pre test (01) & Treatment $(\mathrm{X})$ & Post test (O2) \\
\hline 01 & $(\mathrm{X} 1)$ Media pembelajaran gooogle classroom & 02 \\
03 & $(\mathrm{X} 2)$ Media Pembelajaran whatsap messenger & 04 \\
\hline
\end{tabular}

Tabel 2. Kisi-kisi Soal Hasil Belajar Kognitif

\begin{tabular}{llcc}
\hline \multicolumn{1}{c}{ Indikator Soal } & Ranah Kognitif & No Soal \\
\hline$\checkmark$ & Menyebutkan fungsi hidung dalam proses pernapasan & $\mathrm{C} 1$ & 1 \\
\hline & Menyebutkan fungsi laring & $\mathrm{C} 1$ & 2 \\
\hline & Menyebutkan fungsi alveolus & $\mathrm{C} 1$ & 3 \\
\hline & & \\
\hline
\end{tabular}

\section{Alianto, $d k k$}




\begin{tabular}{llll}
\hline$\checkmark$ & Memahami proses inspirasi & C1 & 5 \\
\hline$\gamma$ & Penyebab frekuensi pernapasan & C2 & 6 \\
\hline$\gamma$ & Memahami macam-macam volume sistem pernapasan & C2 & 7 \\
\hline & Aplikasi dalam sistem penapasan & C3 & 8 \\
\hline$\gamma$ & Gangguan dalam sistem pernapasan & C3 & 9 \\
\hline $\begin{array}{l}\text { Menjelaskan upaya menjaga kesehatan sistem } \\
\text { pernapasan }\end{array}$ & $\mathrm{C} 4$ & 10 \\
\hline
\end{tabular}

\section{HASIL PENELITIAN DAN PEMBAHASAN}

Penelitian ini telah dilakasanakan pada bulan Januari -Maret tahun pelajaran 2020/2021 di Sekolah Menengah Pertama Negeri 4 Bengkulu Tengah. populasi dalam penelitian ini adalah siswa kelas VIII yang berjumlah 86 siswa, dengan sampel berjumlah 43 siswa. Pengumpulan data dengan dengan angket untuk motivasi dan tes pilihan ganda untuk hasil belajar kognitif siswa. Hassil penelitian dapat dilihat pada tabel 3 .

Tabel 3. Tabel Skor Hasil Penelitian Ekperimen Kelas GC dan Kelas WA

\begin{tabular}{clccc}
\hline Kelas eksperimen & Perhitungan & Pre test kognitif & Pos test Kognitif & Jumlah siswa \\
\hline Google Classroom & Jumlah Skor & 1110 & 1610 & \\
& Skor Tertinggi & 80 & 100 & 21 \\
& Skor Terendah & 30 & 60 & \\
& Rata-rata & 52,86 & 76,67 & 22 \\
\hline Whatsapp Mesenger & Jumlah Skor & 1070 & 1660 & \\
& Skor Tertinggi & 60 & 90 & \\
& Skor Terendah & 30 & 60 & \\
& Rata-rata & 48,64 & 75,45 & \\
\hline
\end{tabular}

Dari tabel diatas dapat diketahui bahwa rata-rata hasil belajar kognitif siswa pada kelas Google Classroom skor tertinggi pre test 80 dan skor terendah 30 dengan rata-rata 52,86 sedangkan untuk kelas Whatsapp Mesenger skor pre test skor tertinggi 60 dan skor terendah 30 dengan rata-rata 48,64. Untuk nilai pos test hasil belajar kognitif siswa kelas Google Classroom skor tertinggi 100 dan skor terendah 60 dengan rata-rata 76,67 sedangkan pada kelas Whatsapp Mesenger skor tertinggi 90 dan skor terendah 60 dengan rata-rata 75,45 .

Dari tabel Untuk motivasi belajar siswa pada kelas Google Classroom skor tertinggi 78 dan skor terendah 50 dengan rata-rata 61,07 sedangkan untuk kelas Whatsapp Mesenger skor tertinggi 70 dan skor terendah 48 dengan rata-rata 58,52. Untuk minat belajar siswa pada kelas Google Classroom skor tertinggi 85 dan skor terendah 60 dengan rata-rata 73,81 sedangkan untuk kelas Whatsapp Mesenger skor tertinggi 85 dan skor terendah 43 dengan rata-rata 69,43.

\section{Pengujian Hipotesis}

Pengujian hipotesis dilakukan untuk mengetahui ada atau tidaknya perbedaan hasil belajar kognitif siswa. Adapun hasil pengujian diuraikan dibawah ini:

\section{a. Pretest}

Pada tahap awal dilakukan pretest kemampuan hasil belajar kognitif siswa pada 2 kelas eksperimen dengan jumlah siswa 43 siswa kelas VIII. Hasil uji T-Test skor pretest hasil belajar kognitif siswa dapaat dilihat pada tabel 4 . 
Tabel 4. Uji T -Test Skor Pretest Hasil Belajar Kognitif Siswa

\begin{tabular}{|c|c|c|c|c|c|c|c|c|c|}
\hline & \multirow[b]{2}{*}{$\mathrm{F}$} & \multirow[b]{2}{*}{ Sig. } & \multirow[b]{2}{*}{$\mathrm{T}$} & \multirow[b]{2}{*}{ Df } & \multirow{2}{*}{$\begin{array}{l}\text { Sig. (2- } \\
\text { tailed) }\end{array}$} & \multirow{2}{*}{$\begin{array}{c}\text { Mean } \\
\text { Difference }\end{array}$} & \multirow{2}{*}{$\begin{array}{l}\text { Std. Error } \\
\text { Difference }\end{array}$} & \multicolumn{2}{|c|}{$\begin{array}{c}95 \% \text { Confidence } \\
\text { Interval of the } \\
\text { Difference }\end{array}$} \\
\hline & & & & & & & & Lower & Upper \\
\hline \multirow[t]{2}{*}{ Hasi Pre Test } & .835 & .366 & 1.218 & 41 & .230 & 4.221 & 3.465 & -2.776 & 11.218 \\
\hline & & & 1.211 & 37.810 & .233 & 4.221 & 3.485 & -2.835 & 11.277 \\
\hline
\end{tabular}

Berdasarkan hasil uji T-Test di atas diperoleh nilai sig. (2-tailed) sebesar $0,230>0.05$, maka dapat disimpulkan bahwa tidak ada perbedaan yang signifikan rata-rata hasil belajar siswa antara kelas yang menggunakan google classroom dan kelas yang menggunakan whatsapp messenger.

\section{b. Postest}

Pada tahap akhir dilakukan postest hasil belajar kognitif siswa pada 2 kelas eksperimen dengan jumlah siswa sebanyak 43 siswa kelas VIII. Hasil uji T-Test skor postest hasil belajar kognitif siswa dapat dilihat pada table 5 .

Tabel 5. Tabel Uji T-Test skor Postest Hasil Belajar Kognitif Siswa

\begin{tabular}{|c|c|c|c|c|c|c|c|c|c|}
\hline & \multirow[b]{2}{*}{$\mathrm{F}$} & \multirow[b]{2}{*}{ Sig. } & \multirow[b]{2}{*}{$\mathrm{T}$} & \multirow[b]{2}{*}{ Df } & \multirow{2}{*}{$\begin{array}{l}\text { Sig. (2- } \\
\text { tailed) }\end{array}$} & \multirow{2}{*}{$\begin{array}{c}\text { Mean } \\
\text { Difference }\end{array}$} & \multirow{2}{*}{$\begin{array}{l}\text { Std. Error } \\
\text { Difference }\end{array}$} & \multicolumn{2}{|c|}{$\begin{array}{l}95 \% \text { Confidence } \\
\text { Interval of the } \\
\text { Difference }\end{array}$} \\
\hline & & & & & & & & Lower & Upper \\
\hline \multirow[t]{2}{*}{ Hasi Pos Test } & 1.469 & .232 & .367 & 41 & .716 & 1.212 & 3.305 & -5.463 & 7.887 \\
\hline & & & .365 & 38.378 & .717 & 1.212 & 3.322 & -5.511 & 7.935 \\
\hline
\end{tabular}

Berdasarkan data di atas diperoleh nilai sig. (2-tailed) sebesar 0,716 $>0.05$, maka dapat disimpulkan bahwa tidak ada perbedaan yang signifikan rata-rata hasil belajar siswa antara kelas yang menggunakan google classroom dan kelas yang menggunakan whatsapp messenger.

Tabel 6. Tabel Uji lanjut IST Nilai Pretest dan Postest Hasil Belajar Kognitif Siswa

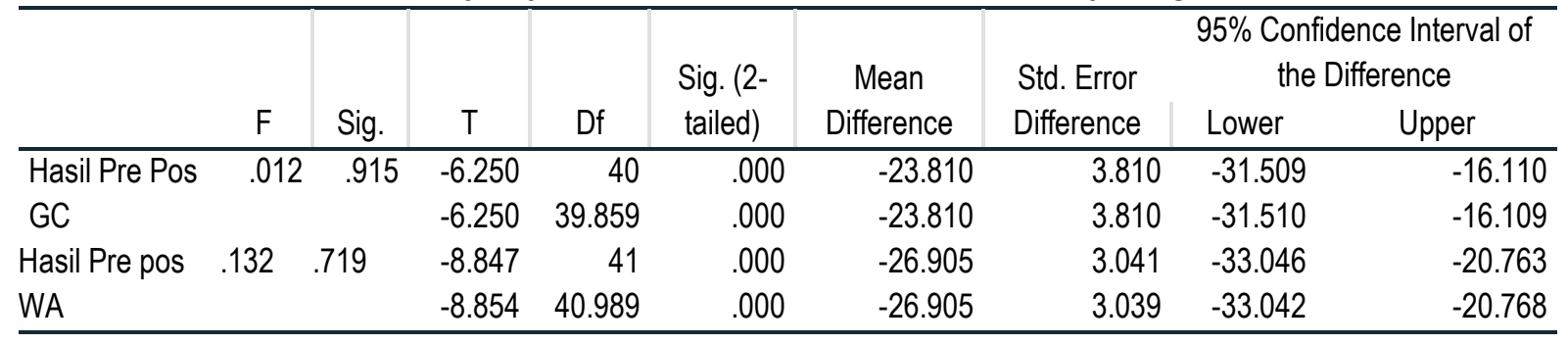

Berdasarkan tabel di atas diperoleh nilai sig. (2-tailed) sebesar $0,000<0.05$, maka dapat disimpulkan bahwa terdapat perbedaan rata-rata hasil belajar siswa antara kelas yang menggunakan belajar google classroom dan kelas yang menggunakan whatsapp mesenger. 


\section{Hasil belajar kognitif siswa pada pembelajaran dengan menggunakan kelas daring Google Classroom dan daring menggunakan Whatsapp Mesenger.}

Berdasarkan tabel 5. diperoleh nilai sig. (2-tailed) sebesar 0,716>0.05, maka Ho diterimah dan Hi ditolak sehingga dapat disimpulkan bahwa tidak ada perbedaan yang signifikan rata-rata hasil belajar siswa antara kelas yang menggunakan google classroom dan kelas yang menggunakan whatsapp mesenger. Sedangkan berdasrkan tabel 6. untuk hasil uji lanjut IST nilai pretest dan posttest nilai sig. (2tailed) sebesar 0,000 < 0.05, maka Ho ditolak dan Hi dititerimah sehingga dapat disimpulkan bahwa terdapat perbedaan rata-rata hasil belajar siswa antara kelas yang menggunakan google classroom dan kelas yang menggunakan whatsapp mesenger.

Dalam penelitian ini data hasil belajar kognitif siswa diperoleh dari nilai hasil test yang dilaksanakan pada awal pertemuan atau pretest dan akhir pertemuan (postest) setelah pembelajaran selesai dilaksanakan. Dilihat dari tabel 5. menunjukkan jumlah responden ada 43 siswa, dari 43 siswa ini berdasarkan data hasil pre test untuk kelas daring Google Classroom dan kelas daring Whatsapp Mesenger, untuk nilai minimum kedua kelas tersebut tidak jauh berbeda, sedangkan nilai maximumnya yang berbeda. Nilai minimum untuk pre test kelas daring Google Classroom dan kelas daring Whatsapp Mesenger adalah sama 30 sedangakan nilai maximum untuk pre test kelas daring Google Classroom 80 dan kelas daring Whatsapp Mesenger adalah nilai maximumnya 60. Mean (rata-rata) pre test untuk kelas daring Google Classroom adalah 52,86 dan kelas daring Whatsapp Mesenger adalah 48,64. Hasil nilai minimum untuk pos test kelas daring Google Classroom adalah 70 dan nilai maximumnya adalah 100 sedangkan kelas daring Whatsapp Mesenger nilai minimumnya adalah 60 dan nilai maximumnya adalah 90. Mean (rata-rata) pos test untuk kelas daring Google Classroom adalah 76,67 dan kelas daring Whatsapp Mesenger adalah 75,45.

Hikmatiar, dkk. (2020) menunjukkan bahwa penggunaan google classroom sebagai media pembelajaran memberikan dampak yang positif terhadap peningkatan hasil belajar pada peserta didik. Agustina (2015) menyatakan terdapat interaksi antara media pembelajaran dan gaya belajar siswa terhadap hasil belajar biologi. Sedangkan penelitian Nurjana, dkk (2020) menyatakan terdapat perbedaan yang signifikan antara hasil belajar peserta didik melalui Virtual Classroom dengan menggunakan Google Classroom dan Whatsapp Group. Selanjutnya Sobron (2020) dalam penelitiannya menunjukkan bahwa terdapat pengaruh penggunaan media Daring Learning terhadap hasil belajar siswa. Puspitorini, dkk (2014) peningkatan hasil belajar kognitif dapat dilihat dengan membandingkan nilai pretes dan postes. Peningkatan hasil belajar kognitif peserta didik diperoleh dengan cara mencari Gain Score. Hasil yang diperoleh menunjukkan bahwa peserta didik mengalami peningkatan hasil belajar kognitif yang terlihat dengan besarnya nilai Gain Score yang diperoleh, yaitu sebesar 0,42 yang tergolong dalam kategori sedang

Ramadhan dan Hasan (2019) menyatakan bahwa hasil belajar kognitif siswa ditentuan oleh siswa itu sendiri berdasarkan usaha yag dimilikinya. Irwandi (2015) menyatakan peningkatan hasil belajar siswa dikarenakan setelah kegiatan belajar mengajar berlangsung dilakukan diskusi refleksi untuk membicarakan tentang aktivitas siswa selama kegiatan belajar mengajar berlangsung dan perbaikanperbaikan untuk kegiatan belajar mengajar. Selanjutnya Menurut Melda, dkk (2019) Faktor yang mempengaruhi kemampuan kognitif berasal dari dalam diri siswa yakni salah satunya adalah minat. Minat sangat besar pengaruhnya terhadap belajar, sebab minat belajar merupakan ketertarikan dan kesukaan 
siswa terhadap bahan pelajaran dan kegiatan belajar yang tentunya akan berujung pada kemampuan kognitif. Perubahan perilaku tersebut bisa dalam hal pengetahuan, afektif dan psikomotoriknya. Dalam proses pembelajaran Pemusatan perhatian sangat diperlukan karena kehadiran minat belajar dalam pribadi seseorang akan merangsang keinginan untuk belajar yang lebih besar.

Berbeda dengan hasil penelitian Nurhayati (2021) mengatakan pembelajaran online berbasis media sosial whatsapp berpengaruh signifikan terhadap peningkatan hasil belajar materi sistem pencernaan peserta didik, sehingga dapat direkomendasikan sebagai model pembelajaran alternatif di masa pandemi. Selanjutnya hasil penelitian Sari, dkk (2021) menunjukkan bahwa hasil belajar kognitif peserta didik mencapai ketuntasan secara klasikal sehingga pembelajaran daring efektif terhadap hasil belajar kognitif peserta didik. Pembelajaran daring tersebut harus diikuti dengaan ketersediaan akses internet sangat diperlukan dalam pembelajaran e-learning, karena karakteristik pembelajaran ini selalu menggunakan dan memanfaatkan jaringan internet. Secara umum, kecepatan akses jaringan internet di Indonesia relatif lambat, ketersediaan jaringan internet yang masih terbatas dan harga untuk mengakses internet relatif mahal sehingga menjadi hambatan bagi pembelajaran e-learning. Begitu pula dengan hasil pembelajaran daring melaui Google Clasroom dan whatsapp di SMPN 4 Bengkulu Tengah memberikan hasil terhadap lajunya proses pembelajaran dengan demikian dapat mengatasi permaslahan kesulitan pembelajaran tatap muka yang tidak bisa dilakukan saat ini.

Dalam hasil penelitian ini tidak terdapat perbedaan antara antara kelas google classroom dengan kelas whatsapp mesenger dikarenakan banyak faktor. Faktor-faktor yang mempengaruhi tersebut antara lain: kurangnya kekuatan sinyal internet yang digunakan untuk proses pembelajaran karena ketersediaan jaringan yang terbatas, mahalnya harga untuk mengakses internet, kurang menariknya aplikasi pemebajaran, banyaknya siswa yang belum memiliki HP android sendiri sehingga harus meminjam dengan orang tua terlebih dahulu, belum menguasai aplikasi, proses pembelajaran jarak jauh menggunakan android merupakan hal yang baru bagi siswa, dan siswa lebih senang bermain game daripada belajar.

\section{SIMPULAN}

Berdasarkan hasil dan pembahasan yang telah dilakukan, maka simpulan yang dapat dikemukan dalam penelitian ini adalah Tidak terdapat perbedaan hasil belajar kognitif siswa pada pembelajaran daring dengan menggunakan Google Classroom dan Whatsapp Mesenger pada pembelajaran IPA di SMPN 4 Bengkulu Tengah. Perolehan rata-rata nilai hasil belajar kognitif siswa di kelas Google Classroom lebih tinggi dibanding dengan kelas Whatsapp Mesenger demikian juga dengan motivasi dan minat belajar.

\section{RUJUKAN}

Herliandry, L, D. dkk. (2020). Pembelajaran Pada Masa Pandemi Covid-19. Jurnal Teknologi Pendidikan, Vol. 22. No. 1

Hikmatiar, H., Sulisworo, D., \& Wahyuni, M. E. (2020). Pemanfaatan Learning Manegement System Berbasis Google Classroom Dalam Pembelajaran. Jurnal Pendidikan Fisika, 8(1), 78-86. https://doi.org/10.26618/jpf.v8i1.3019.

Irwandi, I., \& Sari, A. P. (2015). Penerapan Model Pembelajaran Berbasis Masalah melalui Lesson Study untuk Meningkatkan Hasil Belajar Siswa SMAN 8 Kota Bengkulu. In Proceeding Biology Education Conference: Biology, Science, Enviromental, and Learning (Vol. 12, No. 1, pp. 198-201). 
Kamil, P, M,. K \& Nuryadin, E. (2019). Pengaruh Penggunaan Media Whatsapp (WA) Group Terhadap Hasil Belajar Peserta Didik Pada Materi Sistem Gerak Pada Manusia. Jurnal Pendidikan, Vol. 1. No. 1

Mahardani, M, M, A. (2020). Analisis Situasi Penggunaan Google Classroom Pada Pembelajaran Daring Fisika. Jurnal Pendidikan Fisika Universitas Muhammadiyah Metro, Vol. VIII. No.2. p-ISSN: 23375973

Melda, E., Kashardi, K. \& Hidayat, T., (2019). Kemampuan Kognitif Belajar Siswa dengan menggunakan Model Pembelajaran Inkuiri danProject Based Learning SMPN 5 Seluma. In Seminar Nasional Sains \& Entrepreneurship (Vol. 1, No. 1).

Mendikbud. (2020). Surat Edaran Menteri Pendidikan dan Kebudayaan Nomor 4 Tahun 2020 Tentang Pelaksanaan Kebijakan Pendidikan Dalam Masa Darurat Penyebaran Covid-19. Di akses tanggal 8 Juni 2020

Mu'minah, I, H \& Gaffar, A, A. (2020). "Pemanfaatan E- Learning Berbasis Google Clasroom Sebagai Media Pembelajaran Biologi." Prosiding Seminar Nasional Pendidikan, Vol. 2. No. 1

Nurhayati M, Dakir , Hujjatusnaini. (2021). Analisis Manajemen Pembelajaran Online Berbasis Media Sosial WhatsApp untuk Meningkatkan Motivasi dan Hasil Belajar Siswa Materi Sistem Pencernaan. Jurnal Bioterdidik, Vol. 9 No. 1 page. 22-33

Nurjana, S, Kusuma, A, P, Deswita. (2020). Perbedaan Hasil Belajar Matematika Peserta Didik melalui Virtual Classroom Menggunakan Google Classroom dan WhatsApp Group pada Materi Bilangan Bulat di Kelas VII SMP Al-khairiyah 1 Pagi Jakarta Utara. Prosiding Seminar Nasional Pendidikan STKIP Kusuma Negara II

Puspitorini, R., Prodjosantoso, A. K., Subali, B., \& Jumadi, J. (2014). Penggunaan media komik dalam pembelajaran IPA untuk meningkatkan motivasi dan hasil belajar kognitif dan afektif. Jurnal Cakrawala Pendidikan, 33(3).

Rahartri. (2019). "WHATSAPP" Media Komunikasi Efektif Masa Kini. Jurnal. Visi Pustaka, Vol. 21, No. 2

Rahman, A, J \& Bachtiar, S. (2017). Aktivitas dan Hasil Belajar Siswa Meningkat Melalui Penerapan Model Jigsaw. Jurnal Biologi dan Pembelajaran, Vol. 4. No. 1

Ramadhan, D., \& Hasan, R. (2019). Pengaruh Pembelajaran Model Inkuiri terhadap Keaktifan dan Hasil Belajar Kognitif Siswa di SMK Negeri 2 Pagar Alam. In Seminar Nasional Sains \& Entrepreneurship (Vol. 1, No. 1).

Rikizaputra \& Sulastri, H. (2020). Pengaruh E-Learning dengan Google Classroom terhadap Hasil dan Motivasi Belajar Biologi Siswa. Jurnal Pendidikan, No.11. Vol.1

Sadikin A, \& Hamidah, A. (2020). Pembelajaran Daring di Tengah Wabah Covid-19. Jurnal IImiah Pendidikan Biologi, Vol. 6.No. 2. ISSN: 2580-0922

Sari D, S; Jalmo T; Rahmawati I. (2021) Analisis Efektivitas Pembelajaran Daring Terhadap Hasil Belajar Kognitif Peserta Didik SMA. Jurnal Bioterdidik, Vol. 9 No. 1 page. 59-69 http://jurnal.fkip.unila.ac.id/index.php/JBT/ doi: 10.23960/jbt.v9i107

Sobron, A, N, Sudiatmi, T \& Suswandari, M. (2020). Studi Pengaruh Daring Learning terhadap hasil belajar matematika kelas IV. Jurnal Inovasi Penelitian. Vol 1. No 3

Sugiyono. (2009). Metode Pelitian Pendidikan. Bandung. Alfabeta 